\title{
Efficiency Assessment of Tax Measures in the European Countries Against the Effects of COVID-19
}

\section{Ocena efektywności systemów podatkowych w Europie wobec skutków pandemii COVID-19}

\section{Daria Bilenko*, Serhii Kozlovskyi ${ }^{\star \star}$, Natalya Ivanyuta***, Viktoriia Baidala ${ }^{\star \star \star *}$, Ruslan Lavrov ${ }^{\star \star \star \star *}$, Volodymyr Kozlovskyi}

\author{
*University of State Fiscal Service of Ukraine, \\ Department of Finance named after L.L. Tarangul, Irpin, Ukraine \\ E-mail: belenkodaria1@gmail.com,ORCID:0000-0002-6220-8101 \\ **Vasyl' Stus Donetsk National University, \\ Department of Entrepreneurship, Corporate and Spatial Economics, Vinnytsia, Ukraine \\ E-mail: s.kozlovskyy@donnu.edu.ua,ORCID: 0000-0003-0707-4996 \\ ***Donetsk State University of Internal Affairs, \\ Department of Civil, Labour and Social Security Law, Mariupol, Ukraine \\ E-mail: natalaivanuta9@gmail.com,ORCID:0000-0001-9177-9280 \\ **** National University of Life and Environmental sciences of Ukraine, \\ Department of Economic Theory, Kyiv, Ukraine \\ E-mail: baidala@nubip.edu.ua,ORCID:0000-0002-1532-2913 \\ *****PHEI European University, \\ Department of Finance, Accounting and Taxation, Kyiv, Ukraine \\ E-mail: lavrus2017@gmail.com,ORCID:0000-0002-9655-4467 \\ ******Vinnytsia National Technical University, \\ Department of Enterprise Economics and Production Management, Vinnytsia, Ukraine \\ E-mail:v@vin.ua, ORCID:0000-0002-0955-4347
}

\footnotetext{
Abstract

Ongoing global Covid-19 pandemic is not only health crisis but the economic challenge. The future of society depends on how successfully the authorities find a balance between imposition of stringent restrictions and economic development. Tax policies play a role in reducing losses caused by the Covid-19 lockdowns. All countries are taking tax measures to mitigate the impact of the effects of Covid-19 pandemic on society. While the Covid19 pandemic has not yet been defeated, it is too early to draw conclusions about which tax measures against the effects of Covid-19 are efficient. On the other hand, correct trajectory of economic recovery can be missed if not to analyze the other countries experience. The object of this study is tax measures in the European countries against the effects of Covid-19. The subject of the study is the fuzzy set theory to assess the efficiency of tax measures in the European countries against the effects of Covid-19. The aim of the study is to find out which European countries have been more succeeded in tax measures implementing and type of their immediate crisis response. The analysis is carried out in 29 European countries. The result of the study allows to state that the number of tax measures against the effects of Covid-19 does not affect their efficiency and the most popular type of immediate crisis response has been the business cash-flow enhances.
} 
Key words: Covid-19 (Coronavirus) pandemic, GDP per capita, type of tax, type of immediate crisis response, fuzzy set theory

\section{Streszczenie}

Trwająca globalna pandemia Covid-19 to nie tylko kryzys zdrowotny, ale także wyzwanie gospodarcze. Przyszłość społeczeństw zależy od tego, jak skutecznie władze osiągną równowagę między nakładaniem surowych ograniczeń a rozwojem gospodarczym. Polityka podatkowa odgrywa rolę w ograniczaniu strat spowodowanych przez ograniczenia związane z Covid-19. Wszystkie kraje podejmują inicjatywy podatkowe w celu złagodzenia wpływu pandemii Covid-19 na społeczeństwo. Chociaż pandemia Covid-19 nie została jeszcze pokonana, jest zbyt wcześnie, aby wyciągać wnioski na temat tego, które środki podatkowe przeciwko skutkom Covid-19 są skuteczne. Z drugiej strony można przeoczyć prawidłową trajektorię ożywienia gospodarczego. Przedmiotem tego badania są inicjatywy podatkowe podejmowane w krajach europejskich przeciwko skutkom Covid-19. Przedmiotem badania jest teoria zbiorów rozmytych wykorzystana do oceny skuteczności środków podatkowych w krajach europejskich wobec skutków Covid-19. Celem badania jest ustalenie, które kraje europejskie odniosły większe sukcesy we wdrażaniu środków podatkowych oraz rodzaju ich natychmiastowej reakcji na kryzys. Analiza prowadzona jest w 29 krajach europejskich. Wynik badania pozwala stwierdzić, że liczba inicjatyw podatkowych przeciwko skutkom Covid-19 nie wpływa na ich skuteczność, a najpopularniejszym rodzajem natychmiastowej reakcji na kryzys jest zwiększenie przepływów pieniężnych przedsiębiorstw.

Słowa kluczowe: pandemia Covid-19 (koronawirusa), GDP per capita, typ podatku, rodzaj natychmiastowej reakcji kryzysowej, teoria zbiorów rozmytych

\section{Introduction}

The Covid-19 pandemic has challenged the daily lives of all citizens of the world. To slow the Covid19 spread, lockdown was introduced in the most countries of the world. All European countries had the lockdown for different periods of time both in 2020 and 2021. In the European countries the first lockdown started in Ireland on the 7th of March 2020, the next day Finland joined it. By mod-March, almost all European countries introduced pandemic restriction.

Only one full national lockdown was in Albania, Estonia, Finland, Hungary, Montenegro, Romania, Spain, and Ukraine. The longest one was in Albania (80 days) and the shortest in Finland (20 days). The second nationwide lockdown was at the end of December 2020 in Croatia, Czech Republic, Denmark, Lithuania Netherlands, Portugal, and Switzerland. By regions lockdown was in Germany and Greece and lasted 218 and 181 days respectively. About a year after the first lockdown, several European countries decided on the third lockdown, including Austria, Belgium, Bulgaria, France, Ireland, Italy, Poland, and United Kingdom. In France and United Kingdom lockdown was for regions only. The longest was in Wales for 345 days (statista).

In Europe the first full lockdowns implied not only significant restrictions in public life, but also the shutdown of business. During the second and third lockdowns some European countries have eased restrictions, opening shops and other businesses. Other European countries have switched on the curfew regime for some types of business.

For today the European countries have agreed on a coordinated approach to the movement between countries, vaccination, period of quarantine, but the crisis response for economic recovery was its own.
Among immediate crisis response the most popular has been corporate income tax regulation, value added tax regulation, and personal income tax regulation.

The largest number of measures for corporate income tax regulation was implemented in Poland, none of them in Estonia, Greece, Ireland, Latvia, Montenegro, Slovenia, Switzerland, and Ukraine. Measures to support health system through reducing value added tax and tax payment deferral for business were implemented in almost all European countries, excepting Albania, Denmark, Estonia, Lithuania, Montenegro, Romania, Slovak Republic, and Switzerland. Personal income tax was not regulated in Denmark, Estonia, Finland, Hungary, Moldova, Romania, Serbia, Slovenia, Switzerland, and Ukraine. Least of tax measures were taken in Ukraine (only extension of deadlines for filing income tax returns and asset tax returns) and Latvia (exemption from the advance payments for the taxation year 2020 and extending the rights of the tax administration to divide into time periods), and most of all in Poland (63 tax measures). (Overview of Country Tax Policy measures in response to Covid-19 crisis)

As the lockdown conditions and tax measures are different for European countries, the pandemic consequences are also different. To assess the tax measures efficiency in the European countries against the effects of Covid-19 should be used GDP per capita. Advantage of this index is that it is easy to compare across countries (world databank). The main markers that could indicate tax measures efficiency are presented in the figure 1 .

It can be assumed that there should be a relationship between the duration of lockdown and the tax measures. Since the longer the full national lockdown, the higher the likelihood of business bankru- 


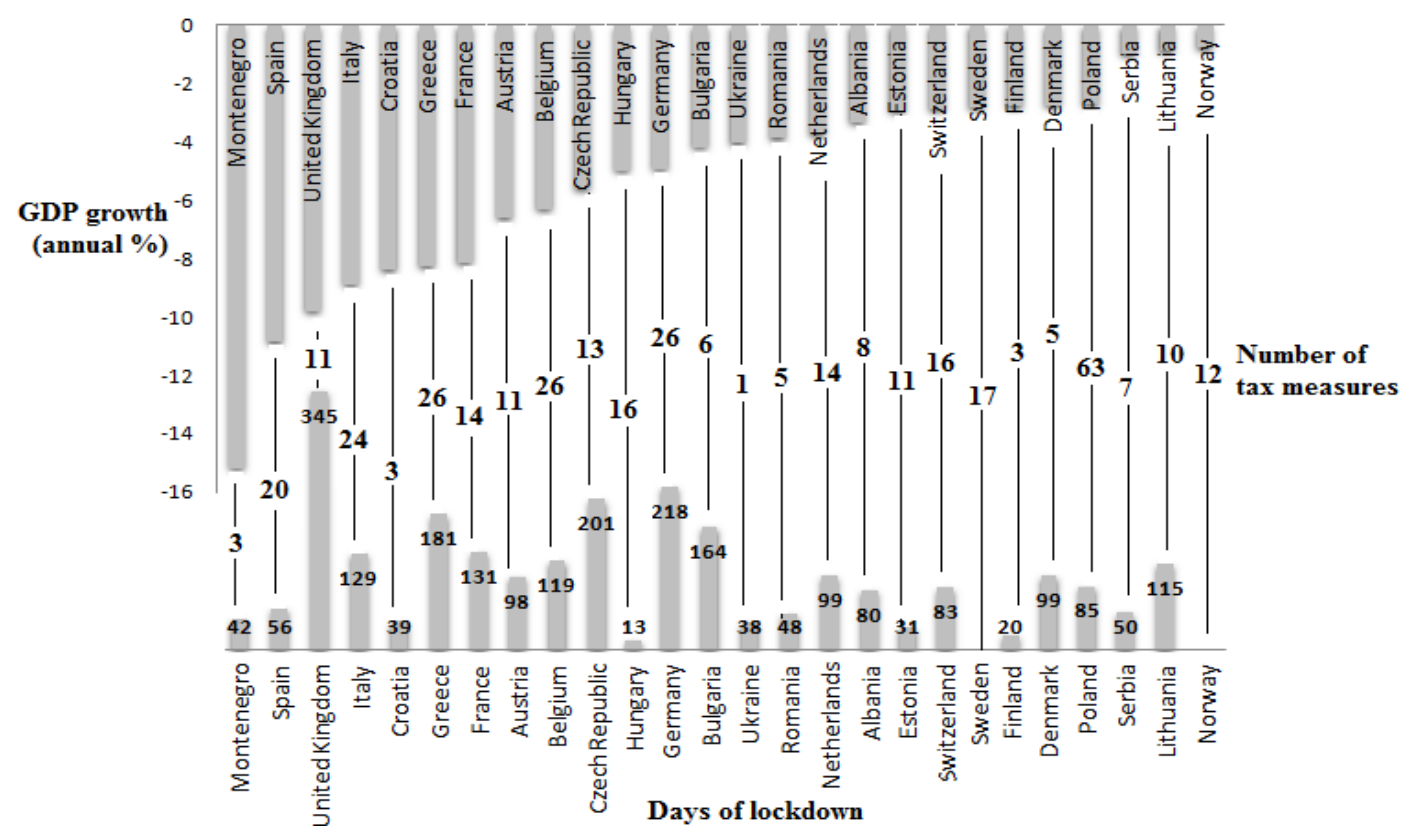

Figure 1. Annual GDP growth in 2020, duration of lockdown and tax measures the European countries (World Bank, 2021)

ptcy and a GDP decline. To prevent it government should take support measures. As it can be seen from Fig. 1, no such pattern is observed. For example, the highest GDP decline is in Montenegro, but there is no long duration of lockdown. Norway implemented 12 tax measures and has the lowest GDP decline. But the other side, Poland implemented 63 tax measures but its GDP decline is higher than in Norway.

The statistical data allow concluding that the key factor affected efficiency of tax measures against the effects of Covid-19 is its qualitative features but not quantitative estimates. Hence, it is of interest to identify those European countries that have succeeded in tax measures implementing.

\section{Background}

For today most international organizations have made the overviews of the tax measures introduced during the COVID-19 crisis.

The Organization for Economic Co-operation and Development (OECD) has developed guidance for policymakers. In it tax policy responses G20 countries and 21 additional members of the OECD/G20 are examined. The conclusions concerns that, on the one hand, strong and timely fiscal support has been key factor to incomes support and keeping businesses afloat and tax packages have focused on recovery-oriented measures, on the other hand, many countries have introduced new tax increases. To a great extent, it applies to developing countries that have a few opportunities to provide fiscal support to households and businesses (Tax policy during the COVID-19 pandemic, 2021).
The next step for OECD has been to develop targeted and temporary tax policy that governments could implement as part of their immediate Covid-19 response (Tax Policy Reforms, 2021).

The International Chamber of Commerce (ICC) in its statements provides expertise for coordinated global response to effectively contain the potential human and economic toll of the COVID-19 pandemic based on its broad network of 45 million businesses. As for tax measures ICC offers for tax administrations to provide an assurance of relief from penalties and interest and deferral or waive of tax payments during pandemic especially for small businesses (ICC statement on related tax measures in response to COVID-19, 2021).

Executive branch of the European Union European Commission (EC) in its communication considerate how to coordinate fiscal policy, taking to the next phase the concerted approach of addressing the pandemic, sustaining the economy, supporting a sustainable recovery and maintaining fiscal sustainability in the medium-term. EC forecasts that Real GDP would reach pre-crisis levels in the second quarter of 2022 but it could not return to its pre-crisis trend by the end of 2022. The recovery is not going to be the same across the European countries. The main national fiscal policy responses were cheap loans to Member States to help them to support workers. In 2020, the Council approved EUR 90 billion for 18 Member States supporting. For the Member States worst affected by the economic fallout of the Covid19 pandemic EUR 312.5 billion of non-repayable support and would be provided (One year since the outbreak of COVID-19: fiscal policy response, 2021). 
One of the largest multinational accounting firm PricewaterhouseCooper (PWC) have gathered and constantly updated tax relief measures that governments have implemented to help business and householders during the Covid-19 pandemic. Information concludes data about personal tax, corporate and other taxes, customs and trade, and compliance and labor (PWC, 2021).

On the one hand, analyzed overviews provides a general idea of taxation trends under Covid-19 pandemic conditions, but, on the other hand, they does not help find out the best way of addressing country's own specific tax challenges. This is due to the fact that, despite the extensive statistical base, methods of analysis and evaluation are not used. The wide range of measures implemented by governments poses a challenge to analysts to compare these policies over time or between countries. In scientific papers attempts to solve this problem have been made. Oxford University's Blavatnik School of Government has offered an approach to assess policy responses around the world. The data are tracked since 1 January 2020, cover more than 180 countries and are coded into 23 indicators. These indicators are recorded on a scale to reflect the extent of government action, and scores are aggregated into a set of policy indices (Blavatnic School of Government, 2021).

In paper (Morales, Rogers-Glabush, 2020) has been made an overview of the tax response of 47 European countries to the challenges imposed by the COVID-19 pandemic. Authors have grouped national measures into categories according to the purpose of each measure and analyzed next steps that should be taken to address the pandemic.

Despite the fact that the COVID-19 pandemic lasts just over a year tax measures in the European countries against the effects of Covid-19 have already been implemented. Relevant reviews of both international organizations and scientific communities have already been published. On the one hand, period of COVID-19 pandemic is too short to assess the efficiency of these tax measures. It means that it is too early to draw final conclusions. On the other hand, a methodological apparatus that would allow assess intermediate results of the tax measures efficiency has been developed.

From here the aim if this paper is to assess the efficiency of tax measures in the European countries against the effects of Covid-19.

\section{Research methodology}

The problem of efficiency assessment of tax measures against the effects of Covid-19 refers to decision-making under conditions of uncertainty. As a rule, to solve such problems the theory of probability is used. In the case of the Covid-19 pandemic, theory of probability is useless. The reason for this is the lack of available data, which does not allow assessing with a sufficient degree of certainty the adequacy of the probabilistic model chosen to describe efficiency of tax measures in the European countries against the effects of Covid-19.

If there is no opportunity to use the statistical analysis methods assessing tax measures against the effects of Covid-19 (Kozlovskyi et. al., 2020), then the source of information is expert assessments. In such conditions, to assessing the existing uncertainty there is a need to use different from probabilistic approach. One of them is fuzzy set theory.

Fuzzy sets were introduced by Zadeh in 1965 as a apparatus for processing natural language utterances (Zadeh, 1965). This theory allows the expert assessment's phrases the tax measures efficiency against the effects of Covid-19 is quite high give a specific mathematical meaning. This makes possible to reduce qualitative expert assessments to quantitative. On the other hand, fuzzy sets provide an expert with great flexibility in evaluating numerical indicators. With regard to the problem of efficiency assessment of tax measures in the European countries against the effects of Covid-19 using the theory of fuzzy sets, it is necessary to solve the following problems:

- to define universal set;

- to construct membership functions;

- to make fuzzy decision where tax measures against the effects of Covid-19 were the most effective (Kozlovskyi et. al., 2019).

Practical use of the theory of fuzzy sets involves constructing membership functions. Its task is to describe in linguistic term the fuzzy set on a universal set $U=\left\{u_{1}, \ldots u_{\mathrm{n}}\right\}$. The fuzzy set is Covid-19 crisis response tax measures. It is proposed to use the number of tax measures in the European countries against the effects of Covid-19 as a universal set.

The next step is to the construct membership function of a fuzzy set Covid-19 crisis response measures on the universal set (Kozlovskyi et. al., 2021).

There are two methods of constructing membership functions. The first one is based on statistical processing of the opinions of a group of experts. The second one is based on pairwise comparisons performed by one an expert (Zimmermann, 2010). Since it is not possible to involve many experts and the results of comparisons are obvious, pairwise comparisons should be used for the efficiency assessment of tax measures in the European countries against the effects of Covid-19. For each pair of elements of a universal set, the advantage of one element over the other is given. Pairwise comparisons are convenient to represent by the following matrix:

$$
\mathrm{A}=\left[\begin{array}{ccc}
a_{11} & \ldots & a_{1 n} \\
\ldots & \ldots & \ldots \\
a_{n 1} & \ldots & a_{n n}
\end{array}\right] .
$$

where $a_{i j}$ is the level of the element's advantage universal set's element $u_{\mathrm{i}}$ over $u_{\mathrm{j}}$ defined on the 9-point comparison scale by Saaty. 
When comparisons are made, it is important to determine whether the more Covid-19 crisis response measures, the better. To determine it, it is necessary to find a relationship between the number of Covid19 crisis response measures and the change in GDP per capita at the same period. The larger the GDP per capita, the more successful the Covid-19 crisis response measures are.

After determining all the elements of the matrix of pairwise comparisons, the degree fuzzy set membership is calculated by the formula:

$$
\mu\left(u_{i}\right)=\frac{1}{a_{1 i}+\cdots+a_{n i}} .
$$

After the membership function of a fuzzy set on the universal set is constructed, it is necessary to make a decision. To make fuzzy decision is to choose European countries where Covid-19 crisis response measures are the best under conditions of uncertainty and lack of information.

\section{Results}

To assess the effectiveness of tax measures in the European countries against the effects of Covid-19 using fuzzy set theory it is necessary to define universal set. As it was shown on Fig.1 the number of tax measures is from 1 in Ukraine to 63 in Poland. 3 out of 29 countries limited themselves to 26 measures, which is almost 2.5 times less than in Poland. From here the universal set is from 0 to 30 with a step of 6. Poland's experience is at the upper end of the universal set.

For constructing membership function of a fuzzy set Covid-19 crisis response measures on the universal set $U=\{0,6,12,18,24,30\}$ expert pairwise comparisons should be formulated.

Since it is completely unclear whether more or fewer Covid-19 crisis response measures are better, then it is necessary to determine the minimum, maximum and average value of GDP per capita for each range of the universal set. The first diapason is from 0 to 5 Covid-19 crisis response measures. In it are Ukraine, Latvia, Croatia, Finland, Montenegro, Denmark, Moldova, and Romania. The second diapason is from 6 to 11 Covid-19 crisis response measures. In it are Bulgaria, Serbia, Albania, Slovak, Republic Lithuania, Austria, Estonia, and United Kingdom. In the diapason from 12 to 17 measures are Norway, Czech, Republic France, Netherlands, Hungary, Switzerland, and Sweden. There are no countries in diapason from 18 to 24 measures. The last diapason includes countries such as Spain, Italy, Belgium, Germany, Greece, and Poland. Data is taken from Fig. 1. Relationship between the number of Covid19 crisis response measures and the change in GDP per capita in 2020 as the results of grouping by diapasons are presented in the table 1 .

It can be seen from table 1 that diapasons $U=\{6,17\}$ has the advantage. A weak advantage can be determened of diapasons $U=\{12,17\}$ over diapasons
$U=\{6,11\}$. From here such expert pairwise comparisons can be formulated:

- absolute advantage of $U=\{12,17\}$ over $U=\{0$, $5\}$;

- clear advantage of $U=\{18,30\}$ over $U=\{0,5\}$;

- significant advantage $U=\{12,17\}$ over $U=\{18$, $30\}$;

- weak advantage of $U=\{12,17\}$ over $U=\{6,11\}$.

These statements correspond to the following pairwise comparisons matrix:

$$
A=\left[\begin{array}{cccc}
1 & 0,11 & 0,11 & 0,14 \\
9 & 1 & 0,33 & 0,2 \\
9 & 3 & 1 & 0,2 \\
7 & 5 & 5 & 1
\end{array}\right]
$$

Applying formula (1), the grade of membership is determined. To normalize a fuzzy set, all the grades of membership should be divided by the maximum value. The graphs of the membership functions of the normal fuzzy set Covid-19 crisis response measures are shown in Fig. 2.

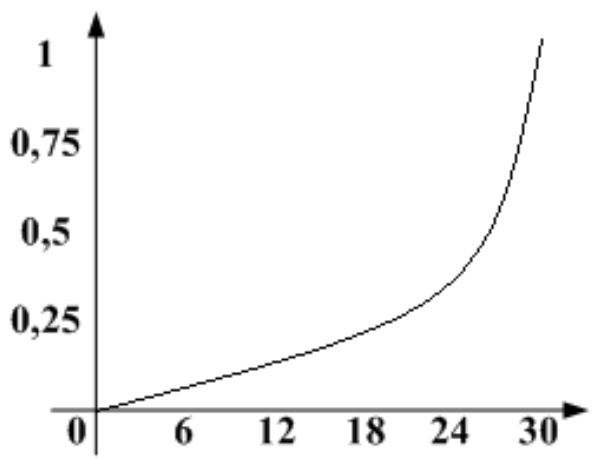

Figure 2. The graphs of the membership functions of the fuzzy set Covid-19 crisis response measures

As it can be seen, a large number of Covid-19 crisis response measures do not guarantee their effectiveness. European countries that are successfully recovering from Covid-19 pandemic have implemented from 6 to 18 measures. It is likely that the content of Covid-19 crisis response measures does not increase with their number. At the same time, the number of measures less than six does not allow to overcome the crisis consequences caused by the pandemic.

European countries can be roughly divided into 2 groups. In the first group there are countries that have focused on three main types of taxes, such as corporate income tax (CIT), corporate income tax (PIT), value-added tax (VAT). These countries are Albania, Austria, Bulgaria, Czech, Netherlands, Norway, Lithuania, and Slovak. In the first place among tax measures in these countries against the effects of Covid-19 is VAT and CIT. The second group includes countries that have introduced unique experiences based on their political traditions and economic realities. There are Estonia, Hungary, France, Serbia, Sweden, Switzerland, and United Kingdom. In all European countries where the tax measures against the effects of Covid-19 have been more suc- 
Table 1. Relationship between the number of Covid-19 crisis response measures and the change in GDP per capita in 2020

\begin{tabular}{|c|c|c|c|}
\hline \multirow{2}{*}{$\begin{array}{l}\text { The universal set } \\
U=\{0,6,12,18,24,30\}\end{array}$} & \multicolumn{3}{|c|}{ GDP per capita growth, annual \% } \\
\hline & minimal & average & maximum \\
\hline Diapason $U=\{0,5\}$ & $-15,16$ & $-5,94$ & $-2,73$ \\
\hline Diapason $U=\{6,11\}$ & $-9,79$ & $-4,17$ & $-0,87$ \\
\hline Diapason $U=\{12,17\}$ & $-8,11$ & $-4,12$ & $-0,76$ \\
\hline Diapason $U=\{18,30\}$ & $-10,84$ & $-6,97$ & $-2,70$ \\
\hline
\end{tabular}

Table 2. List of more successful tax measures in the European countries against the effects of Covid-19

\begin{tabular}{|c|c|c|c|c|c|c|c|c|c|}
\hline & \multicolumn{4}{|c|}{ Type of tax } & \multicolumn{5}{|c|}{ Type of immediate crisis response } \\
\hline & CIT & PIT & VAT & Other & $\begin{array}{l}\text { business cash- } \\
\text { flow enhance }\end{array}$ & $\begin{array}{l}\text { household } \\
\text { cash-flow } \\
\text { enhance }\end{array}$ & $\begin{array}{l}\text { health sys- } \\
\text { tem support }\end{array}$ & $\begin{array}{l}\text { employ- } \\
\text { ment sup- } \\
\text { port }\end{array}$ & other \\
\hline Albania & 4 & 1 & - & 3 & 4 & 3 & - & 1 & - \\
\hline Austria & 1 & 5 & 2 & 3 & 4 & 1 & 5 & 1 & - \\
\hline Bulgaria & 1 & 1 & 1 & 3 & 2 & 1 & 1 & 1 & 1 \\
\hline Czech & 3 & 3 & 9 & 2 & 5 & 2 & 1 & - & 9 \\
\hline Estonia & - & - & - & 11 & 4 & - & - & - & 7 \\
\hline Hungary & 2 & - & 1 & 13 & 4 & 1 & 5 & - & 3 \\
\hline Netherlands & 3 & 1 & 3 & 7 & 12 & - & 2 & - & - \\
\hline Norway & 2 & 2 & 2 & 6 & 10 & - & - & - & 2 \\
\hline France & 1 & 1 & 1 & 11 & 9 & - & 1 & - & 4 \\
\hline Lithuania & 3 & 1 & 6 & - & 3 & - & 1 & 1 & 5 \\
\hline Serbia & 1 & 1 & 1 & 4 & 3 & 2 & 1 & 1 & - \\
\hline Slovak & 4 & 1 & - & 2 & 6 & 1 & - & - & - \\
\hline Sweden & 2 & 2 & 2 & 11 & 6 & 2 & 2 & 3 & 4 \\
\hline Switzerland & - & - & - & 16 & 10 & - & - & - & 6 \\
\hline United Kingdom & 2 & 1 & 2 & 6 & 5 & 1 & 1 & 1 & 3 \\
\hline
\end{tabular}

cessful the most popular type of immediate crisis response has been the business cash-flow enhances. Only Czech, Estonia, and Lithuania have preferred not typical than business cash-flow and household cash-flow enhance, health system and employment support types of immediate crisis response.

\section{Discussion}

Efficiency assessment of tax measures in the European countries against the effects of Covid-19 refers to multiobjective decision making. In this paper GDP per capita is used as the only criterion. On the one hand, this approach to efficiency assessment of tax measures against the effects of Covid-19 narrows the result. On the other hand, there are reliable and easy comparable statistics on GDP per capita. It makes results of efficiency assessment is more trustworthy.

The other point of discussion is the universal set division of diapasons. In this paper it was proposed to use step 6 for expert pairwise comparisons and membership functions construction. If the step were more or less, then the relationship between the number of Covid-19 crisis response measures and the change in GDP per capita could be different. If to sort the European countries by the number of tax measures, and plot the graph by GDP per capita, then the trend in the middle of the graph towards a decrease in the decline in GDP is seen. It means that the size of the diapason has no fundamental effect.
In addition, European countries were not initially in the same conditions when the Covid-19 pandemic had started. Less developed countries did not have sufficient safety margin to implement Covid-19 crisis response measures as developed countries could afford themselves. The political systems of European countries have their own features that affect the speed of decision-making. Different European countries, applying exactly the same experience, can get different results. That's why as a methodology, it is proposed to use the theory of fuzzy sets, which does not indicate the only correct solution, but suggests for study just list of more successful tax measures in the European countries against the effects of Covid19.

\section{Conclusion}

Assessing the efficiency of tax measures in the European countries against the effects of Covid-19 using the fuzzy set theory let make such conclusions:

- the number of tax measures against the effects of Covid-19 does not affect their efficiency;

- the most advantageous number of tax measures against the effects of Covid-19 is from 6 to 18;

- European countries that have succeeded in tax measures implementing are Albania, Austria, Bulgaria, Czech, Estonia, France, Hungary, Lithuania, Netherlands, Norway, Serbia, Slovak, Sweden, Switzerland, and United Kingdom; 
- European countries that have implemented from 6 to 18 tax measures equally either preferred value-added tax and corporate income tax regulation or have introduced their unique experience;

- the most popular type of immediate crisis response has been the business cash-flow enhances in European countries that have implemented from 6 to 18 tax measures.

\section{References}

1. COVID-19 Government Response Tracker, 2021, Blavatnic School of Government, https://ig.ft.com/coronavirus-lockdowns/.

2. ICC Statement on Related Tax Measures in Response to COVID-19, 2021, https://iccwbo.org/ publication/icc-statement-on-related-tax-measuresin-response-to-covid-19/.

3. KOZLOVSKYI S., BILENKO D., KUZHELIEV M., LAVROV R., KOZLOVSKYI V., MAZUR H., TARANYCH A., 2020, The system dynamic model of the labor migrant policy in economic growth affected by COVID-19, Global Journal of Environmental Science and Management, 6(SI): 95-106, DOI: 10.22034/GJESM.2019.06.SI.09.

4. KOZLOVSKYI S., BILENKO D., DLUHOPOLSKYI O., VITVITSKYI S., BONDARENKO O., KORNIICHUK O., 2021, Determinants of COVID19 Death Rate in Europe: Empirical Analysis, Problemy Ekorozwoju/ Problems of sustainable development, 16(1): 17-28.

5. KOZLOVSKYI S., PETRUNENKO IA., BAIDALA V., MYRONCHUK V., KULINICH T., 2021, Assessment of public welfare in Ukraine in the context of the COVID-19 pandemic and economy digitalization, Problems and Perspectives in Management, 19(1): 416-431,

DOI: $10.21511 / \mathrm{ppm} .19(1) .2021 .35$.

6. KOZLOVSKYI S., BUTYRSKYI A., POLIAKOV B., BOBKOVA A., LAVROV R., IVANYUTA N.,
2019, Management and comprehensive assessment of the probability of bankruptcy of Ukrainian enterprises based on the methods of fuzzy sets theory, Problems and Perspectives in Management, 17(3): 370-381,

DOI: 10.21511/ppm.17(3).2019.30.

7. Legal and Tax Relief Measures on COVID-19 Pandemic, 2021, https://www.pwc.com/th/en/tax/legaland-tax-relief-measures-on-covid-19-pandemic.htm 1.

8. MORALES T., ROGERS-GLABUSH J., 2020, European Union/International - Emergency Tax Measures in Response to the COVID-19 Pandemic: The Full Picture in Europe, European Taxation, 60(7): 269-287.

9. Overview of Country Tax Policy Measures in Response to COVID-19 Crisis OECD, 2021, Tax policy during the COVID-19 pandemic, OECD Publishing, Paris, https://www.oecd.org/tax/tax-policy/tax-policy-during-the-covid19-pandemic-flyer.pdf.

10. One year since the outbreak of COVID-19: fiscal policy response, 2021, Communication from the commission to the council, Brussels, https://ec.europa.eu/info/sites/default/files/economyfinance/1_e n_act_part1_v9.pdf.

11. OECD, 2021, Tax Policy Reforms 2021: Special Edition on Tax Policy during the COVID-19 Pandemic, OECD Publishing, Paris, DOI: $10.1787 / 427 \mathrm{~d} 2616-\mathrm{en}$.

12. STATISTA, 2021, https://www.statista.com/statistics/1196071/covid-19-vaccination-rate-in-europeby-country/ (20.09.2021).

13. WORLD BANK, 2021, World Bank Indicators, https://data.worldbank.org (20.09.2021).

14. ZADEH L.A., 1965, Fuzzy sets, Information and Control, 8(3): 338-353, http://www.cs.berkeley.edu/ $\sim$ zadeh/papers/Fuzzy Sets-Information and Control1965.pdf.

15. ZIMMERMANN H.-J., 2010, Fuzzy set theory, $A d$ vanced Review, John Wiley \& Sons, Inc. 2: 317-332. https://www.mv.helsinki.fi/home/niskanen/zimmermann_review.pdf. 